\title{
NOTE
}

\section{Comparison of growth rates between estuarine and coastal reef populations of Achoerodus viridis (Pisces: Labridae)}

\author{
Bronwyn M. Gillanders*
}

School of Biological Sciences A08, University of Sydney, NSW 2006, Australia

\begin{abstract}
Patterns of abundance and size-frequency distributions of Achoerodus viridis (Pisces: Labridae) in the Sydney region (New South Wales, Australia) showed greater numbers of small fish $(<200 \mathrm{~mm}$ standard length, SL) on estuarine reefs than on open coastal reefs. In contrast, open coastal reefs had greater densities of large fish (>200 mm SL) Growth of $A$. viridis was therefore investigated to determine to what extent differences in size-frequency distributions between estuarine and open coastal reefs could be explained by slower growth at estuarine reefs compared to open coastal reefs. No significant differences in growth of $A$. viridis were found between estuarine and coastal reef sites. Spatial differences in size-frequency distributions are most likely due to movement of fish from estuarine to coastal reefs, rather than differences in growth of fish
\end{abstract}

KEY WORDS: Reef-fish - Growth - Size-frequency $\cdot$ Temperate

Many studies on temperate reef fish have accumulated information on patterns of abundance and size structure of populations, but few of the mechanisms underlying these patterns have been well established (Jones 1988). Size-frequency distributions, as opposed to age-frequency distributions, are usually presented as a description of the structure of populations. Where differences in size-frequency distributions are found for different areas (e.g. depths) or times (e.g. seasons), such information has been used to suggest movement (e.g. Leum \& Choat 1980, Choat \& Ayling 1987, Jones 1988, McCormick 1989, Gillanders \& Kingsford 1993). Few studies that have shown differences in size-frequency distributions have also determined the age of the fish. This is unfortunate because information on age may be used to test whether the observed patterns

\footnotetext{
- Present address: Faculty of Fisheries and Marine Environment, Australian Maritime College, PO Box 21, Beaconsfield, Tasmania 7270 , Australia.

E-mail: gillanders@vision.net.au
}

are due to differences in growth of fish or to other factors (e.g. movement, mortality).

Of the post-recruitment demographic variables, growth is probably the most sensitive to environmental conditions (Jones 1991). Growth may be highly variable after settlement to the reef, and thus can have a major influence on the size structure of adult populations between different areas (Jones 1991). Other indirect effects of growth may also occur, since the resulting size of fish may be important in terms of mortality rates, maturation times and systematic movements (Hughes 1984, Kirkpatrick 1984, Jones 1988, 1991).

Spatial patterns in density and size structure of Achoerodus viridis (Pisces: Labridae) in the Sydney region (Australia) have previously been described (Gillanders \& Kingsford 1993, Gillanders in press). The proportion of small fish ( $<200 \mathrm{~mm}$ standard length, SL) decreased from estuarine sites to open coastal reefs and between shallow and deep areas of reef within a site. Large A. viridis (>200 $\mathrm{mm}$ SL) showed greater numbers at both depths of open coastal reef sites than at estuarine sites. This pattern was found in estuaries separated by $20 \mathrm{~km}$ and at smaller spatial scales of locations (each side of estuary) within an estuary (separated by $4 \mathrm{~km}$; Gillanders in press). Size-frequency distributions showed that the mean size of fish was smaller on estuarine reefs (mean size $\pm \mathrm{SE}$ : $184 \pm 5 \mathrm{~mm}$ SL) than on open coastal reefs (288 $\pm 4 \mathrm{~mm}$ SL). Possible explanations for these patterns include a range of recruitment and post-recruitment demographic processes (i.e. mortality, growth, movement, habitat choice).

Growth of fish was investigated to test whether the observed differences in size-frequency distributions between estuarine and open coastal reefs could to some extent be explained by slower growth at estuarine sites compared to sites at open coastal reefs. If growth of fish on estuarine reefs was less than that of 
fish on open coastal reefs, then small fish on estuarine reefs may be of comparable age to those of large fish on open coastal reefs. The objective of this paper was therefore to determine the extent that patterns of growth could explain patterns of abundance and size structure of Achoerodus viridis.

Materials and methods. Fish were collected by spear-fishing from 4 estuarine sites (Middle Head, Breakwall, Sutherland Point and Oak Park) and from 4 open coastal reef sites (North Head, Little Bay, Cape Solander and Jibbon Bombora). Sites were located in 3 estuaries and their adjacent open coastal reefs (Port Jackson, $33^{\circ} 50^{\prime} \mathrm{S}, 151^{\circ} 17^{\prime} \mathrm{E}_{\text {; }}$ Botany Bay, $34^{\circ} 00^{\prime} \mathrm{S}$, $151^{\circ} 14^{\prime} E_{i}$ and Port Hacking, $34^{\circ} 05^{\prime} \mathrm{S}, 151^{\circ} 09^{\prime} \mathrm{E}$ ), all of which are in the Sydney region on the east coast of NSW, Australia. Approximately 15 fish between 180 and $350 \mathrm{~mm}$ SL were collected from each site. SL $( \pm 1 \mathrm{~mm})$ for each fish was recorded. Sagittal otoliths were removed, cleaned in water and stored dry in glass vials for later age determination. A sagittal otolith from each fish was embedded in a block of Spurr's resin and ground using a series of sandpaper and lapping film to within a few microns of the primordium on one side. The polished surface of each block was glued to a glass slide and the block was ground and polished from the opposite side to the primordium to produce $a$ thin section. Thin sections of otoliths showed a concentric pattern of light (translucent) and darker brown (opaque) bands or increments when viewed under transmitted light. Counts of the opaque increments were used to estimate ages of fish. Otoliths were read using a light microscope at 40 to $100 \times$ (transmitted light). All otoliths were examined separately without knowledge of fish size or locality. Marginal increment analysis of otoliths has previously provided a partial validation of the ageing technique for this species (Gillanders 1995).

At each site linear regression lines were fitted between age and SL; these regression lines were then compared. The statistical significance of the effects [estuary vs open coastal reef (= location), and site (nested within location)] was estimated by a 2-way (location and site) nested analysis of covariance (ANCOVA; following Huitema 1980). Homogeneity of observed residual variances around the regression line for each site was tested using Cochran's $C$-test (Winer et al. 1991). Statistical independence of the covariate (i.e. SL) was tested by performing an ANOVA on SL. An additional assumption in this analysis is that the data to be analysed have the same slope for the regression equation. Slopes of the set of regression equations were therefore compared before analysis of the adjusted means was attempted. If the slopes differed, there was no valid basis for a comparison of the intercepts using ANCOVA (Huitema 1980. Underwood 1981).
Heterogeneous slopes were found, therefore 2 additional types of analyses were performed. Although the overall homogeneity of regression hypothesis was rejected, this does not mean that all slopes differed from each other. The overall homogeneity test was therefore followed up with additional homogeneity tests for groups of sites at each location and on all combinations of pairs of slopes (Huitema 1980). Groups of sites with homogeneous slopes were then analysed with ANCOVA, and the Johnson-Neyman procedure was used for comparisons involving groups with heterogeneous slopes (Huitema 1980). The Johnson-Neyman procedure identifies values of SL that may be associated with significant differences in ages of fish between sites, and therefore allows statements to be made regarding regions of non-significance and significance (Huitema 1980).

Peterson \& Black (1987) also described an analysis that may be used where heterogeneous slopes are found. For each site, a regression equation was used to calculate the age of fish at each of 3 lengths $(220,270$, and $320 \mathrm{~mm} \mathrm{SL}$ ). Separate ANOVAs were performed on the expected age of fish for each SL. This alternative analysis avoids the unjustified use of a common slope in making calculations and extends the generality of the results through analysis of growth at a number of lengths. This analysis is, however, conservative in that each site generates a single data point (Peterson \& Black 1987).

Results and discussion. Growth was similar, for a limited size range ( 150 to $350 \mathrm{~mm} \mathrm{SL}$ ) of fish, among all 8 estuarine and open coastal reef sites, except the Breakwall site (Fig. 1). The Breakwall site was the only artificial habitat and only 10 fish were collected there with few fish over $200 \mathrm{~mm}$ SL $(\mathrm{n}=6)$. To have a balanced analysis with equal numbers $(n=15)$ of fish from each site, the Breakwall site and a randomly selected open coastal reef site (Jibbon Bombora) were not used in the nested ANCOVA. The ANCOVA revealed heterogeneous slopes, suggesting that fish from different sites experienced different growth rates (Table 1). Although other studies have found large variations in growth of fish among areas (e.g. Jones 1980, 1984, 1986, Thresher 1983, 1985, Gladstone \& Westoby 1988), none have determined whether differences in growth occur between estuarine and open coastal reefs

Growth was similar among estuarine sites; ANCOVA found homogeneous slopes $\left(F_{2,39}=1.619, \mathrm{p}>\right.$ $0.2)$ and no significant differences among sites $\left(F_{2,41}=\right.$ $0.704, p>0.5$, therefore, fish at different sites on estuarine reefs showed similar growth rates. There were heterogeneous slopes for open coastal reef sites $\left(F_{2,39}=\right.$ $5.158, p<0.01$ ) and this was caused by differences in slopes between Cape Solander and Little Bay. As a 


\section{Estuarine reefs}
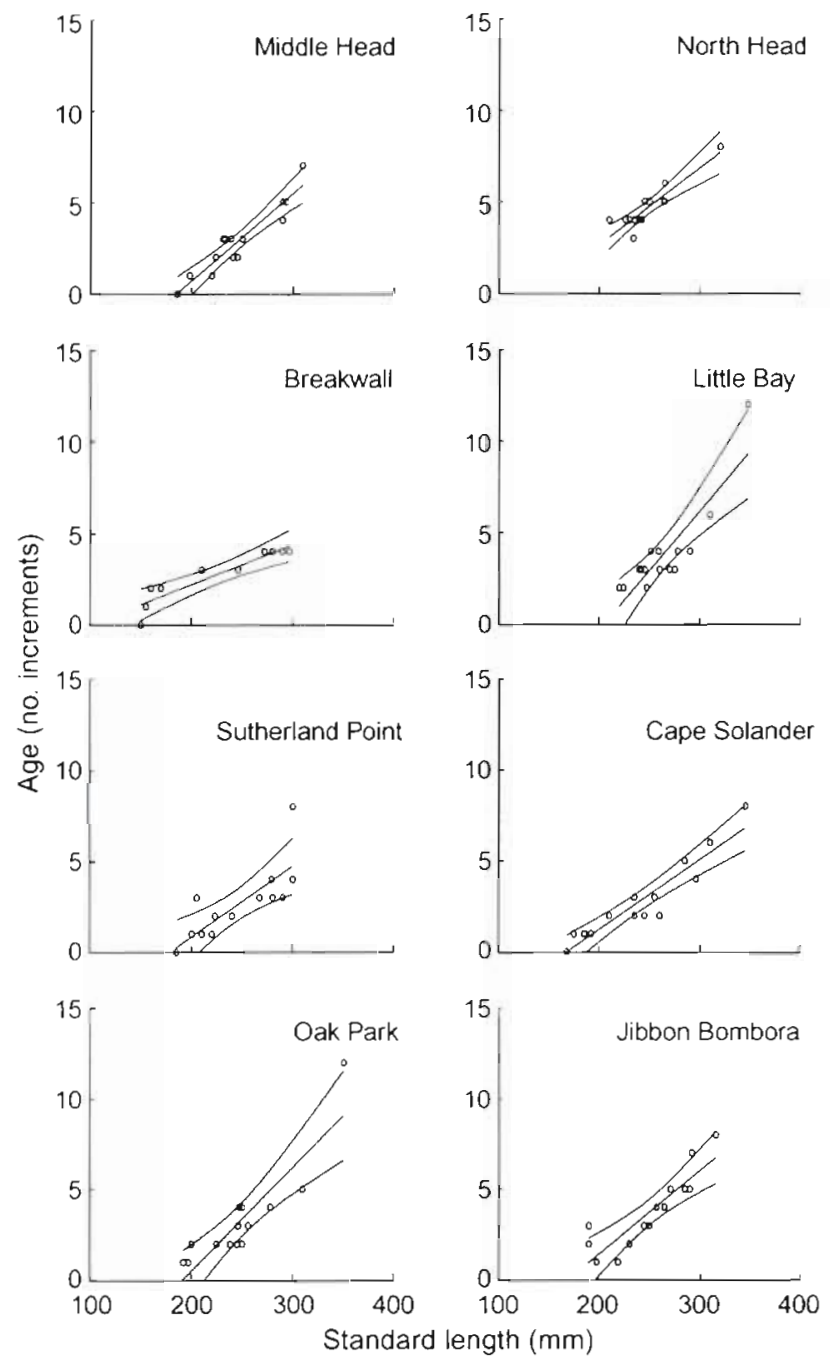

Fig. 1 Achoerodus viridis. Relationship between age and standard length for adult fish from estuarine and open coastal reef sites from Port Jackson, Botany Bay and Port Hacking $(\mathrm{n}=15$, except Breakwall where $\mathrm{n}=10)$. Shown are regression lines through the data $\pm 95 \%$ confidence intervals

consequence, the Johnson-Neyman procedure was used for comparison of growth between Cape Solander and Little Bay. This procedure showed no significant difference in growth of fish between 258 and $303 \mathrm{~mm} \mathrm{SL}$, but fish less than $258 \mathrm{~mm}$ SL at Cape Solander were older than fish from Little Bay. The reverse was true for fish greater than $303 \mathrm{~mm} \mathrm{SL}$, although few fish greater than this size were included in the analysis. Homogeneous slopes were found for all other comparisons between sites $(p>0.05)$. ANCOVA showed that fish at North Head (open coastal reef site) were older than fish at all other sites (Table 2), the reverse pattern to that expected if growth was an important model for explaining differences in size fre-
Table 1. ANCOVA table comparing growth of Achoerodus viridis showing calculations for heterogeneity of slopes and the model used for the analysis fonly presented to illustrate model, Cochran's $C=0.2803$, not significant (ns) at 0.05 , variances 6 , df 14; ANOVA on standard length ns). Location refers to estuarine or open coastal reefs. $F$ vs $=$ mean square denominator $\cdot \mathrm{p}<0.05$

\begin{tabular}{|lrccc|}
\hline Source of variation & df & MS & F-ratio & Fvs \\
\hline Heterogeneity of slopes & 5 & 2.4298 & 2.474 & \\
Individual residual & 78 & 0.982 & & \\
Within residual & 83 & & & \\
1 Covariate (i.e. SL) & 1 & 281.483 & 263.148 & 4 \\
2 Location & 1 & 9.167 & 1.453 & 3 \\
3 Site\{location\} & 4 & 6.307 & 5.896 & 4 \\
4 Residual & 83 & 1.07 & & \\
\hline
\end{tabular}

quency distributions between estuarine and open coastal reefs.

Although mean ages were consistently lower for each size $(220,270,320 \mathrm{~mm} \mathrm{SL})$ from estuarine reefs, no significant difference in age of fish between locations on estuarine and open coastal reefs was detected (Fig. 2, Table 3). Hence, there was no suggestion that fish on estuarine reefs grew more slowly than those on open coastal reefs.

Spatial or temporal differences in the size distributions of a population may reflect changes in recruitment of young, mortality, growth or movement into or out of the population. Estuarine reefs showed greater numbers of small fish and decreased numbers of large fish compared to open coastal reefs (Gillanders in press). Such patterns are not caused by spearfishing, as the species is protected from spearfishing. Recreational line fishers are known to remove Achoerodus viridis from open coastal reefs (A. Steffe pers. comm.), but little is known of the intensity of fishing at inner estuarine sites. Small fish on estuarine reefs might be expected to show slow growth compared to similarly sized fish on open coastal reefs because small fish on estuarine reefs occur at greater densities (e.g. Jones 1984). It has been observed that in many organisms, including plants, the first response to crowding is a decrease in mean size

Table 2. Adjusted mean and SE for ANCOVA between pairs of sites where significant differences and homogeneous slopes were found (i.e. North Head and all other sites)

\begin{tabular}{|lccc|}
\hline Site & $\begin{array}{c}\text { Site } \\
\text { Adjusted mean }\end{array}$ & $\begin{array}{c}\text { North Head } \\
\text { Adjusted mean }\end{array}$ & SE \\
\hline Sutherland Point & 2.6 & 4.5 & 0.237 \\
Middle Head & 2.9 & 4.6 & 0.149 \\
Oak Park & 3.2 & 4.7 & 0.256 \\
Cape Solander & 2.9 & 4.5 & 0.167 \\
Little Bay & 3.4 & 5.1 & 0.260 \\
\hline
\end{tabular}


Table 3. ANOVA table for 3 standard lengths of Achoerodus viridis. Cochran's C-test, variances 2 , df $2: 220 \mathrm{~mm} \mathrm{SL}, C=0.999$, significant at $0.05 ; 270 \mathrm{~mm} \mathrm{SL}, C=0.791, \mathrm{~ns}$ at $0.05 ; 320 \mathrm{~mm} \mathrm{SL}, C=0.578$, ns at 0.05

\begin{tabular}{|lcccccccc|}
\hline & & \multicolumn{2}{c}{$220 \mathrm{~mm}$ SL } & \multicolumn{2}{c|}{$270 \mathrm{~mm} \mathrm{SL}$} & \multicolumn{2}{c|}{$320 \mathrm{~mm} \mathrm{SL}$} \\
Source of variation & df & MS & F-ratio & MS & F-ratio & MS & F-ratio \\
\cline { 4 - 4 } & 1 & 0.337 & 0.430 & 0.386 & 0.733 & 0.438 & 0.436 \\
Residual & 4 & 3.133 & & 2.105 & & 4.014 & \\
\hline
\end{tabular}

with increasing density (Forrester 1990). Fish have extremely plastic growth rates (Weatherley 1990) and therefore a reduction in growth at increased densities would be more likely than mortality (Forrester 1990). Although fish on estuarine reefs were smaller on average than fish on open coastal reefs, fish of the same size from the 2 types of reef were of a similar age. Growth of A. viridis, therefore, did not explain differences in sizefrequency and abundance patterns of fish between estuarine and open coastal reefs.

Although differences in size-frequency distributions were found between estuarine and open coastal reefs, these differences did not appear to be related to slow growth of fish at estuarine reefs. At the smaller spatial scale of sites, differences in growth were found. Other demographic parameters, such as recruitment, mortality and movement, appear to be more likely explanations of large scale differences in the size-frequency distributions of Achoerodus viridis (see Gillanders \& Kingsford 1996).

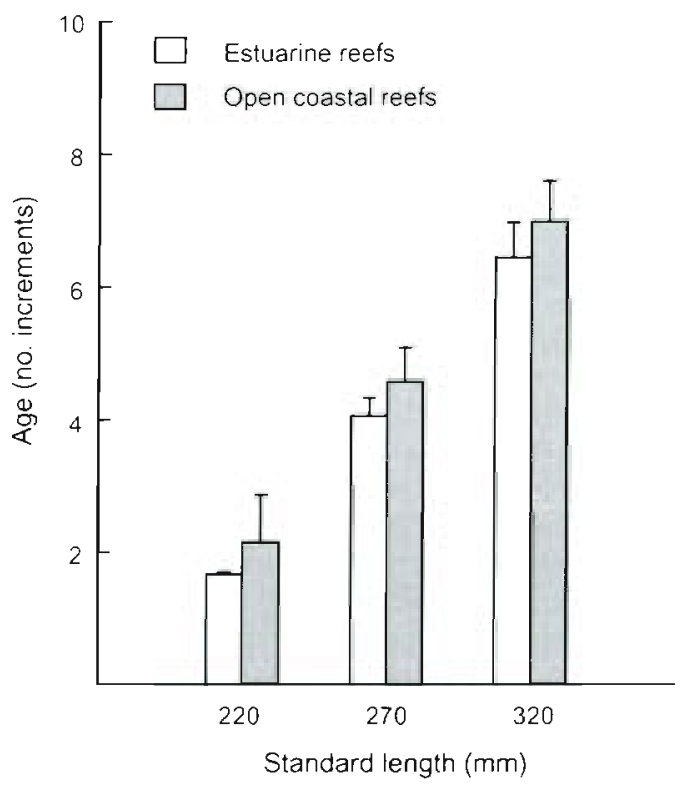

Fig. 2. Achoerodus viridis. Mean age (+SE) of fish at 3 standard lengths for estuarine and open coastal reef sites $(n=3)$. Ages were calculated from the regression equations for fish at each site
Acknowledgements. [ thank K. Butler, S. Connell, M. Finn, N. Gallahar, T. Glasby, A. Hepworth, M. Kingsford, K. Moore, G. Moreno, K. Tricklebank and V. Tzioumis for help with field collections of fish. This work was conducted while B.M.G. held an Australian Postgraduate Research Award. Financial support was provided by an ARC grant to Mike Kingsford and by the University of Sydney through research funding. Constructive comments on previous versions of the manuscript were given by S. Connell, M. Haddon, D. Worthington and 4 anonymous referees.

\section{LITERATURE CITED}

Choat JH, Ayling AM (1987) The relationship between habitat structure and fish faunas on New Zealand reefs. J Exp Mar Biol Ecol 110:257-284

Forrester GE (1990) Factors influencing the juvenile demography of a coral reef fish. Ecology 71:1666-1681

Gillanders BM (1995) Reproductive biology of the protogynous hermaphrodite Achoerodus viridis (Labridae) from south-eastern Australia. Mar Freshwat Res 46: $999-1008$

Gillanders BM (in press) Patterns of abundance and size structure in the blue groper Achoerodus viridis (Pisces: Labridae): evidence of links between estuaries and coastal reefs. Environ Biol Fish

Gillanders BM, Kingsford MJ (1993) Abundance patterns of Achoerodus viridis (Pisces: Labridae) on estuarine and exposed rocky reefs: possible linkages. In: Battershill CN, Schiel DR, Jones GP, Creese RG, MacDiarmid AB (eds) Proc 2nd Int Temperate Reef Symp. Auckland, New Zealand. NIWA Marine, Wellington, p 93-98

Gillanders BM, Kingsford MJ (1996) Elements in otoliths may elucidate the contribution of estuarine recruitment to sustaining coastal reef populations of a temperate reef fish. Mar Ecol Prog Ser 141:13-20

Gladstone W. Westoby M (1988) Growth and reproduction in Canthigaster valentini (Pisces, Tetraodontidae): a comparison of a toxic reef fish with other reef fishes. Environ Biol Fish 21:207-221

Hughes TP (1984) Population dynamics based on individual size rather than age: a general model with a reef coral example. Am Nat 123:778-795

Huitema BE (1980) The analysis of covariance and alternatives. John Wiley and Sons, New York

Jones GP (1980) Growth and reproduction in the protogynous hermaphrodite Pseudolabrus celidotus (Pisces: Labridae) in New Zealand. Copeia 1980:660-675

Jones GP (1984) Population ecology of the temperate reef fish Pseudolabrus celidotus (Pisces: Labridae). II. Factors influencing adult density. J Exp Mar Biol Ecol 75:257-276

Jones GP (1986) Food availability affects growth in a coral reef fish. Oecologia 70:136-139

Jones GP (1988) Ecology of rocky reef fish of north-eastern New Zealand: a review. NZ J Mar Freshwat Res 22: $445-462$

Jones GP (1991) Postrecruitment processes in the ecology of coral reef fish populations: a multifactorial perspective. In Sale PF (ed) The ecology of fishes on coral reefs. Academic Press, San Diego, p 294-328

Kirkpatrick M (1984) Demographic models based on size, not age, for organisms with indeterminate growth. Ecology 65:1874-1884

Leum LL, Choat JH (1980) Density and distribution patterns 
of the temperate marine fish Cheilodactylus spectabilis (Cheilodactylidae) in a reef environment. Mar Biol 57: 327-337

McCormick MI (1989) Spatio-temporal patterns in the abundance and population structure of a large temperate reef fish. Mar Ecol Prog Ser 53:215-225

Peterson $\mathrm{CH}$, Black R (1987) Resource depletion by active suspension feeders on tidal flats: influence of local density and tidal elevation. Limnol Oceanogr 32:143-166

Thresher RE (1983) Habitat effects on reproductive success in the coral reef fish, Acanthochromis polyacanthus (Poma-

This note was submitted to the editor centridae). Ecology 64:1184-1199

Thresher RE (1985) Distribution, abundance, and reproductive success in the coral reef fish, Acanthochromis polyacanthus. Ecology 66:1139-1150

Underwood AJ (1981) Techniques of analysis of variance in experimental marine biology and ecology. Oceanogr Mar Biol Annu Rev 19:513-605

Weatherley AH (1990) Approaches to understanding fish growth. Trans Am Fish Soc 119:662-672

Winer BJ, Brown DR, Michels KM (1991) Statistical principles in experimental design. McGraw-Hill, Inc, New York

Manuscript first received: April 2, 1996

Revised version accepted: November 1, 1996 